\title{
The nurse's work in the context of COVID-19 pandemic
}

\author{
Trabalho do enfermeiro no contexto da pandemia de COVID-19 \\ Trabajo del enfermero en el contexto de la pandemia de COVID-19
}

Valéria Gomes Fernandes da Silva' ORCID: 0000-0003-1381-8664

Bruno Neves da Silva' ORCID: 0000-0001-9854-4492

Érika Simone Galvão Pinto' ORCID: 0000-0003-0205-6633

Rejane Maria Paiva de Menezes ORCID: 0000-0002-0600-0621

'Universidade Federal do Rio Grande do Norte. Natal, Rio Grande do Norte, Brazil.

How to cite this article: Fernandes da Silva VGF, Silva BN, Pinto ESG, Menezes RMP. The nurse's work in the context of COVID-19 pandemic. Rev Bras Enferm. 2021;74(Suppl 1):e20200594. doi: http://dx.doi.org/10.1590/0034-7167-2020-0594

\section{Corresponding author:}

Valéria Gomes Fernandes da Silva E-mail: valeriafernandes7@hotmail.com

EDITOR IN CHIEF: Dulce Barbosa ASSOCIATE EDITOR: Alexandre Balsanelli

Submission: 06-05-2020
Approval: 10-31-2020

\begin{abstract}
Objective: Reflect on the work experienced by the nurse in coping with the COVID-19 pandemic in a public hospital of the State of Rio Grande do Norte. Methods: Reflective essay based in the professional experience in a public reference hospital for the care of patients affected by COVID-19 in the State of Rio Grande do Norte. Results were organized in two empirical categories, which emphasize potentialities and barriers in the nurse's work in the face of the COVID-19, presented by means of Ishikawa diagram. Results: Two categories emerged from the experiences: Nursing leadership in organizing health services to face COVID-19; and the performance of nursing care management in the COVID-19 pandemic. Final considerations: It is necessary to value the nurse's work in all its attributes, as well as strengthen the interdisciplinary work processes, which collaborate to overcome the crisis caused by the pandemic.

Descriptors: Work; Nurses; Pandemics; Nursing Care; Health Services.
\end{abstract}

\section{RESUMO}

Objetivo: Refletir sobre o trabalho experienciado pelo enfermeiro no enfrentamento da pandemia de COVID-19 vivenciado em um hospital público do estado do Rio Grande do Norte. Métodos: Ensaio reflexivo embasado na vivência profissional em um hospital público de referência para atendimento de pacientes acometidos pela COVID-19 no estado do Rio Grande do Norte. Os resultados foram organizados em duas categorias empíricas, que destacam as potencialidades e entraves do trabalho do enfermeiro diante da COVID-19, apresentados por meio do diagrama de Ishikawa. Resultados: Duas categorias emergiram das experiências vivenciadas: Protagonismo da enfermagem na organização dos serviços de saúde para o enfrentamento da COVID-19; e O exercício da gerência dos cuidados de enfermagem na pandemia de COVID-19. Considerações finais: Necessita-se valorizar o trabalho do enfermeiro em todos os seus atributos, bem como fortalecer os processos de trabalho interdisciplinares, que colaboram para a superação da crise ocasionada pela pandemia. Descritores: Trabalho; Enfermeiro; Pandemia; Cuidados de Enfermagem; Serviços de Saúde.

\section{RESUMEN}

Objetivo: Reflejar sobre trabajo vivido por el enfermero frente a la pandemia de COVID-19 experimentado en un hospital público en Rio Grande do Norte. Métodos: Ensayo reflexivo basado en vivencia profesional en un hospital público de referencia para atención de pacientes acometidos por COVID-19 en Rio Grande del Norte. Los resultados se organizaron en dos categorías empíricas, que destacan las potencialidades y entrabes del trabajo del enfermero delante la COVID-19, presentados por medio del diagrama de Ishikawa. Resultados: Dos categorías emergieron de las experiencias vividas: Protagonismo de enfermería en la organización de los servicios de salud para el enfrentamiento de COVID-19; y El ejercicio de la gerencia de los cuidados de enfermería en la pandemia de COVID-19. Consideraciones finales: Necesita valorizar el trabajo del enfermero en todos sus atributos, bien como fortalecer los procesos de trabajo interdisciplinares, que colaboran para la superación de la crisis ocasionada por la pandemia.

Descriptores: Trabajo; Enfermero; Pandemia; Cuidados de Enfermería; Servicios de Salud. 


\section{INTRODUCTION}

The world experiences the challenge to fight against the new human coronavirus (SARS-CoV-2) proliferation. It is a newly discovered virus that, together with other six types of its species, constitutes an etiologic agent responsible for developing the COVID-19 (coronavirus 2019 disease), characterized as an acute viral infection highly disseminate and lethal, with increasing proportions, which repercussion is seen in different global realities ${ }^{(1)}$.

According to the World Health Organization (WHO), the disease arises in January 2020 as a considerable public health emergency of International importance, and later, in March of the same year, it was classified as a pandemic. Up to the present (June $3^{\text {rd }}$ ), it takes high proportions, being responsible for the infection of $6,287.771$ individuals and generates 379,941 deaths in the world since the beginning of pandemic in December 2019, in China ${ }^{(2)}$.

In Brazil, the high infectivity accompanies the global growth perspective; and, in two months of pandemic, COVID-19 in Brazil stands out in the number of cases confirmed, with 584,016, and 32,548 number of deaths up to June $3^{\text {rd(3) }}$. In the State of Rio Grande do Norte, in this same period, 9,149 confirmed cases and 367 deaths caused by the disease were registered ${ }^{(3)}$. Although the high number, there a great uncertainty regarding the epidemiologic route in Brazilian scenario, which transcends the official data due to the underreporting of cases generated by unavailability of testing that confirms the diagnosis in a large part of the National territory ${ }^{(4)}$.

The social and health impact caused by the COVID-19 pandemic, determined, in part, by the uncertainty of the virus control strategies, as the development of a vaccine and the resistance to review the physical/social isolation, run through by different contexts of the Brazilian nation ${ }^{(5)}$. In the field of health, assistance services experience a sudden change in the work routines of the professionals, and the progressive increase in contagion and the consequent overcrowding in the provision of public and private services call the attention of sanitary authorities ${ }^{(6)}$.

In this context, health professionals face the dilemma between carrying out actions of promotion and care assistance to people suspected of being infected by the virus or to those already diagnosed with COVID-19. They face an atypical work reality ${ }^{(7)}$, many times followed of still incipient knowledge regarding the behavior of the disease, the increased demand that generates hospital overcrowding and the lack of knowledge about the diagnosis of a patient already at the hospital. Those factors make the hospital scenario scary before a highly virulent pathology with severe clinical presentation, which results in an operational instability of all health system ${ }^{(7)}$.

In the meantime, the nurse's work is highlighted, a professional category whose figure as head of the nursing team and member of health team, occupies a relevant space in the front line of fighting the pandemic. In his work context in the hospital environment, he carries out specific activities associated to technical capabilities of a care practice, which usually implies the management of health systems and services and include the development of educational activities, which have an equal degree of importance ${ }^{(8)}$.

As a reflection of this pandemic, the great challenge to be faced by those professionals in view of the opposition between the need to implement resolute assistance based on specific operational protocols for COVID-19 and the impairment of the working conditions offered, considered indispensable in the care subsidy surrounded by an instrumental apparatus fundamental to their protection and safety in carrying out nursing care, when assisting a hospitalized patient with COVID- $19^{(7)}$.

In this perspective, the relevance of highlighting the nuances about the nurse's work context in the current health situation caused by COVID-19, since they give opportunity to reflect about the work of those professionals under multiple views, being able to help in the elaboration of strategies that include changes and make their professional work more effective.

\section{OBJECTIVE}

Reflect on the work experienced by the nurse in coping with the COVID-19 pandemic in a public hospital of the State of Rio Grande do Norte.

\section{METHODS}

This is a reflective and descriptive essay. In the current scenario caused by the pandemic, the empirical professional experience was taken as a basis in a reference hospital for COVID-19 located in the State of Rio Grande do Norte. The results of the study are presented by means of a formulation of two analytical categories, build with the use of semantic criterion (generalist categories encompassing the themes that emerged from experiences), and originated in this scenario of care, in which the nurse has an important role.

After the description and reflective analysis, a Ishikawa diagram was built, also known as fishbone diagram, which consist of quality management tool for assistance in health services, in addition to relating in its graphic representation, the causes (primary and secondary) and effect of a situation care. It favors the best view of a reality in a way that its elaboration is reflected in the performance of interventions.

Its structure is built from an issue or effect, represented on the right of the diagram, referring to the idea of the "fish's head". In this direction, a horizontal line is traced; and from it, some diagonal lines are traced downward and upward. In their bases, resumes the primary causes, which are the items to which the problems are comprehensively related. Finally, among the diagonal lines, there are the secondary causes ${ }^{(9)}$.

This layout aimed to summarize the main barriers identified in the related experience.

\section{RESULTS}

Two categories were built to analyze reflexively the nurse's work before the COVID-19 pandemic in Brazil. Category 1: Nursing leadership in organizing the services for coping; Category 2: The work of care management in the face of the crisis.

\section{Category 1: Nursing leadership in organizing health ser- vices in coping the COVID-19}

The organization and development of rules, routines, protocols, and care flows of health services and systems are activities 
intrinsic to the health team. They facilitate and guide the accomplishment of actions and/or activities that systematize the care offers in this scenario.

In the COVID-19 pandemic context, nursing team acts as leader in the organization of services for assuming the frontline to provide inputs and required materials, since the order, receipt checking until the distribution in the sectors, in addition to training the other health professionals regarding their use.

This pandemic brought peculiarities in the ways of acting in public health services, which demand complete reorganization of physical structure, and health practices developed by the nursing team and by the multidisciplinary and interdisciplinary team.

Among the main modifications arising from the pandemic, stand out: the planning of key areas either for the vestment of the professionals (aiming to avoid virus contamination), or the installation of washrooms and purges; the elaboration of rules, routines, and standard operational protocols (POPs), and their precaution peculiarities, adapting the care and nursing proceedings to patients with COVID-19; and the sizing of human resources considering a possible reduction of the team, due to a probable contamination of those professionals anytime.

Nursing also acts developing flows to the maintenance of body fluids, and manipulation of related devices (such as probes, suction flasks and drains), protocols for the organization of hygiene needs, nutrition, oxygenation, acid-base balance, among other items.

Regarding the nutrition needs, flows were established for the installation of supplementary oxygen supply devices that would minimize aerosol formation by patients, such as the use of catheters without humidifier or intubation using hemostat and piece for sealing the endotracheal. In order to meet the nutrition requirements, the established flows involves disinfection of enteral diets, orientation regarding the trays, cutlery, and other utensils used for this purpose, among other established routines.

It is worth noting that, despite the existence of a multidisciplinary team in the hospital routine, which develops direct care actions to the patient, as well as the management by sector, the nursing team somehow assumes a leadership in the development of such activities, even if it is not the only "duty", since it also acts in establishing flows for the entire multidisciplinary team in addition to the nursing team.

The nurse leadership is nationally highlighted by other researchers, who emphasize the effective and incisive work of those professionals fighting directly against the new coronavirus, or in associated areas, highlighting the need of a recognition of this professional category in the face of its relevance for the public health in Brazil ${ }^{(10)}$.

\section{Category 2: The work of nursing care management in the COVID-19 pandemic}

Despite facing undeniable challenges, potentially causing stress and psycho suffer in the analyzed context, nursing performs the management of nursing care, as well as the actions dedicated to the promotion and prevention of care, necessary to control and combat the virus in patients with positive diagnosis. Professionals experience the clash of feelings of virtue, due to the sense of accomplishment, with the feeling of devaluation in the face of difficulties and/or obstacles in the care of patients affected by COVID-19.

In the midst of this conflict are both structural and psychosocial factors and aspects related to the health services. Regarding structural factors, the issue of professional valorization of nursing has long been discussed, such as the establishment of a worthy wage floor and the consolidation of a work week of 30 hours, nationally. And even if those subjects are in the route of discussion by legislature, its effectiveness is still being debated by political representation.

It is understood that some reasons that contribute to it are: low nursing representativeness in politics; and the lack of mobilization of the category, which, despite being the largest SUS workforce, is little valued by society that consider the physician as the center of the provision of healthcare influenced by a preserved curative care model.

Regarding the health services, the activities routine of the nurse involves dealing with the lack of basic inputs, and in COVID-19 context, with the lack of personal protection equipment that assures their safety to perform care. Another aspect that stands out is the human resources deficiency, which burdens the active professionals and results from the inappropriate sizing, mainly in times of crisis, when there should be a safety technical index to guarantee the absences.

In addition, despite the adverse scenario caused by the new coronavirus crisis, the nurse has, in many occasions, to deal with inflexible managers, who practice autocratic leadership, and end up generating a wear out of the interpersonal relationships, which results in more obstacles in developing the work, leading to frustrations.

Regarding psychosocial factors, despite the situations of death and dying permeate the professional performance of nurses, the emotional wear out caused by living this process in higher scale, also increases their anxiety regarding the fear of self-contamination or cross-contamination of loved ones, mainly because of the direct assistance that nursing provides to the patient near the bedside, 24 hours a day.

Also, the physical wear out of the professionals during working hours, already exhausting due to the reasons mentioned above, is aggravated due to the vestment required to assist patients with COVID-19, both to excessive heat, increased by the Brazilian weather, liquid intake restriction and feeding as well as the use of toilet. The professionals still face pressure injuries caused by the use of individual protection equipment.

However, despite the various existing barriers, nurses are able to exercise the practice with satisfaction, mainly because they know that they are a key member in the health area, necessary to fight against the new coronavirus, and their leadership directly contributes to improve the public health in Brazil, impacting the rehabilitation of several social actors.

It is in this perspective that the organized civil society has praised the nursing professional's actuation, considering them heroes. However, the use of this designation brings with it the inconvenience of causing the dehumanization of these individuals who, at this moment, in addition to social prestige, need better work conditions, appropriate remuneration and work hours, and psychosocial support. This is because they also 
get sick, wear out and overburden themselves in all aspects experienced by the new pandemic, unlike what one would expect from a superhero.

This reality calls the attention to the need to review important aspects related to the work routine of the nurse in the hospital environment, and studies shows the urgency of reformulations either in the field of public health policies turned to the protection of workers, or in the health system, as a way to combat the existing impasses that generate impacts on the routine of the professional, especially the nurse's work ${ }^{(5)}$.

Guided by the intellections resulted from experiences, the existence of barriers arouse from multiple factors was perceived, which contribute so that the actions and care provided by nurses to patients affected by COVID-19 become exhausting in the context of the coronavirus crisis.

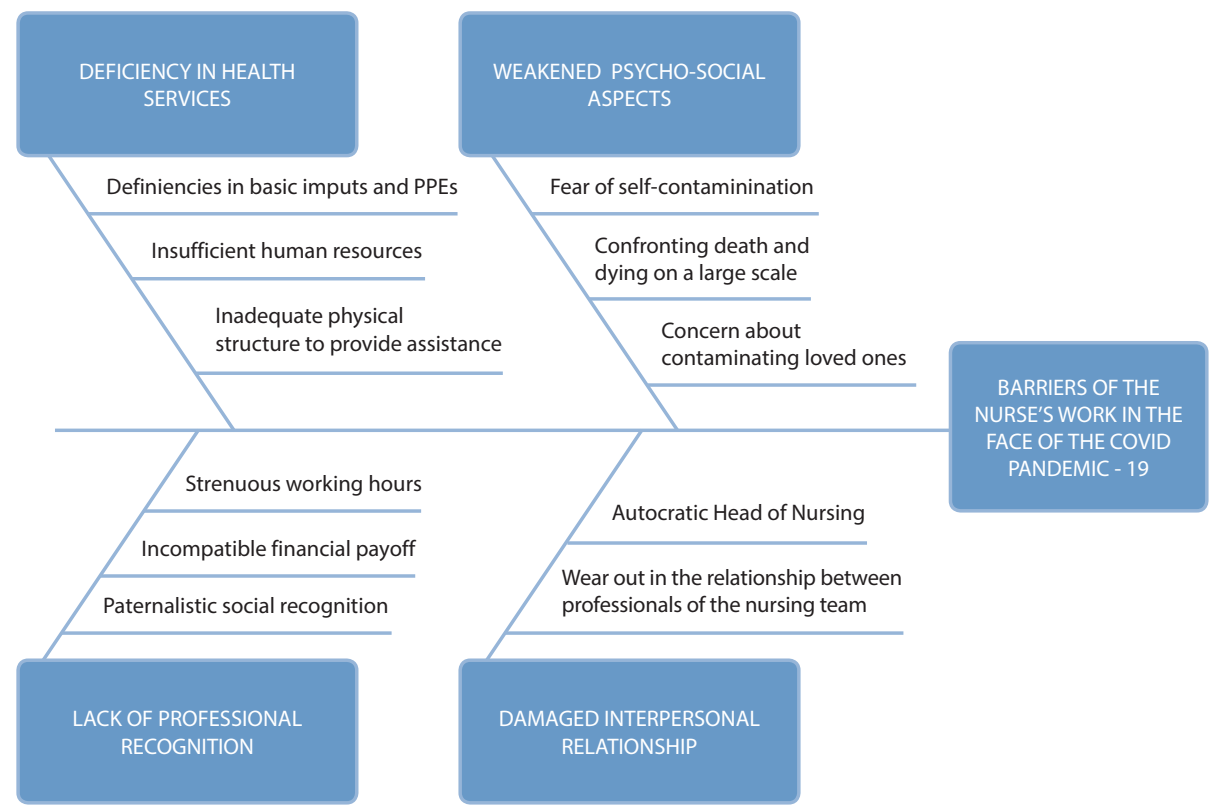

Figure 1 - Ishikawa Diagram
For a better visualization of these results, the Ishikawa diagram below represents a systematized chart, exemplifying the primary and secondary causes that lead the nurses to wear out in developing their actions and care during the COVID-19 pandemic.

\section{FINAL CONSIDERATIONS}

Considering both the present world public health emergency caused by SARSCoV-2 and the results presented, some emerged difficulties in health service was observed due to the need of adjustments to face a pathogen that most of its characteristics are still unknown. In this context, the role of the nurse stands out, because his role in organizing the frontline of services and managing of care proves its relevance.

However, many other factors that frequently cause wear out in the performance of the nurse are identified, mainly those related to little professional recognition, lack of material and personal in care services, as well as to psychosocial and interpersonal aspects.

In this perspective, it is necessary to value the nurse's work in all their attributes, as well as strengthen interdisciplinary work processes, which collaborate to overcome the crisis caused by the pandemic.

As a limitation of the study, it is highlighted that the reflections elaborated came from a local experience. Although they had already been mentioned in the literature, they may not represent the contexts in which nurses work in the face of the pandemic in other realities. However, they contribute to the recognition of the prominent role of this professional in crisis scenarios.

\section{REFERENCES}

1. Xu Z, Shi L, Wang Y, Zhang J, Huang L, Zhang C, et al. Pathological findings of COVID-19 associated with acute respiratory distress syndrome. Lancet Respir Med. 2020;8(4):420-22. doi: 10.1016/S2213-2600(20)30076-X

2. World Health Organization (WHO). Coronavirus disease (COVID-19) Situation Report: 135 [Internet]. Geneva: World Health Organization; 2020 [cited 2020 Jun 04]. Available from: https://www.who.int/docs/default-source/coronaviruse/situation-reports/20200603-covid-19sitrep-135.pdf?sfvrsn=39972feb_2

3. Ministério da Saúde (BR). Painel de casos de doença pelo coronavírus 2019 (COVID-19) no Brasil [Internet]. Brasília: Ministério da saúde; 2020 [cited 2020 Jun 04]. Available from: https://covid.saude.gov.br/.

4. Gaete R. Covid-19 Brasil Análise subnotificação [Internet]. 2020 [cited 2020 May 10]. Available from: https://ciis.fmrp.usp.br/covid19/ analise-subnotificacao

5. Rafael RMR, Neto M, Carvalho MMB, David HMSL, Acioli S, Faria MGA. Epidemiology, public policies and Covid-19 pandemics in Brazil: what can we expect? Rev Enferm UERJ. 2020;28:e49570. doi: 10.12957/reuerj.2020.49570

6. Ministério da Economia (BR). Instituto de Pesquisa Econômica e Aplicada. Nota técnica Mapeamento dos profissionais de saúde no Brasil: alguns apontamentos em vista da crise sanitária da covid-19 º30 [Internet]. Brasília: Ministério da Economia; 2020. [cited 2020 May 10]. Available from: http://repositorio.ipea.gov.br/bitstream/11058/9837/1/NT_30_Diest_Mapeamento\%20dos\%20Profissionais\%20de\%20 Sa\%c3\%bade\%20no\%20Brasil.pdf 
7. Gallasch CH, Cunha ML, Pereira LAS, Silva-Jr JS. Prevenção relacionada à exposição ocupacional: COVID-19. Rev Enferm UERJ. 2020;28:e49596:1-6. doi: 10.12957/reuerj.2020.49596

8. Silva JCB, Silva AAOB, Oliveira DAL, Silva CC, Barbosa LMS, Lemos MEP, et al. Perfil do enfermeiro na gestão dos serviços hospitalares. Rev Enferm UFPE. 2018;12(10):2883-90. doi: 10.5205/1981-8963-v12i10a236307p2883-2890-2018

9. Wong KC. Using an Ishikawa Diagram as a Tool to Assist Memory and Retrieval of Relevant Medical Cases from the Medical Literature. J Med Case Rep. 2011;5:120. doi: 10.1186/1752-1947-5-120

10. Alves JCR, Ferreira MB. COVID-19: Reflexão da atuação do enfermeiro no combate ao desconhecido. Enferm Foco [Internet]. 2020 [cited 2020 Sep 10];11(1):74-7. Available from: http://revista.cofen.gov.br/index.php/enfermagem/article/view/3568/806 